\title{
复 \\ Performance and carcass quality of Nellore and F1 Rubia Gallega $\times$ Nellore young bulls supplemented with chromium picolinate
}

\author{
[Desempenho e características de carcaça de garrotes Nelore e F1 Nelore e Rubia Galega \\ suplementados com cromo picolinato]
}

"Artigo Científico/Scientific Article"

\author{
Paulo Sérgio Andrade Moreira ${ }^{1 *}$, Angelo Polizel Neto ${ }^{1}$, Celina Palhari $^{1}$, Felipe Ferreira Faria $^{1}$, \\ Leonardo Virgilio Gregório Guimarães ${ }^{1}$, André Mendes Jorge ${ }^{2}$
}

\begin{abstract}
${ }^{1}$ Programa de Pós-Graduação em Zootecnia, Universidade Federal de Mato Grosso, Campus Sinop, Sinop-MT, Brasil. ${ }^{2}$ Departamento de Produção Animal, Faculdade de Medicina Veterinária e Zootecnia, Universidade Estadual Paulista, Botucatu-SP, Brasil.

*Autor para correspondência/Corresponding author: E-mail: paulomoreira@ufmt.br
\end{abstract}

\begin{abstract}
Resumo
Supplementation with chromium may be an alternative to beef production. The objective was to evaluate the performance and carcass quality of uncastrated Nellore (NEL) and F1 Rubia Gallega $\times$ Nellore (RGN) young bulls receiving protein-energy supplementation containing chromium picolinate $(\mathrm{CrP})$. Sixty young bulls (30 NEL and $30 \mathrm{RGN}$ ) with an initial weight of $232.40 \pm 0.0 \mathrm{~kg}$, average age of 210 days, were distributed in a completely randomized design in a $2 \times 2$ (genetic groups and supplementation with and without $\mathrm{CrP}$ ) factorial arrangement. The experimental period was 335 days, including 15 days of adaptation, divided into two stages: post-weaning (210 days) and finishing period (110 days) and slaughtered at 530 days of age. No interaction effect ( $>0.05$ ) between genetic group and CrP was detected. During the post-weaning period, the RGN animals showed a higher average daily gain $(\mathrm{ADG})$ than the NEL $(0.65 \times 0.49 \mathrm{~kg} / \mathrm{day})$, while in the finishing stage, ADG was similar ( $\mathrm{p}=0.162$ ) between the groups. Supplementation with $\mathrm{CrP}$ elevated $(\mathrm{p}=0.021)$ ADG by $50 \mathrm{~g} /$ day in the post-weaning stage, but lowered it by $130 \mathrm{~g} /$ day in the finishing stage. Genetic group and the use of $\mathrm{CrP}$ did not affect ( $p>0.05$ ) loin-eye area, subcutaneous fat thickness, hot carcass weight, carcass dressing percentage, carcass conformation, or degree of fatness. The RGN young bulls have better performance and higher muscle and bone tissue development rates than the NEL. Supplementation with CrP does not influence the carcass quality, but accelerates muscle development in the post-weaning stage.
\end{abstract}

Palavras-chave: carcass yield; chromium; intake; minerals; ultrasound.

\begin{abstract}
Suplementação com cromo pode ser uma alternativa para intensificar a produção de carne bovina. O Objetivo foi avaliar o desempenho produtivo e a qualidade de carcaça de bovinos não castrados da raça Nelore (NEL) e F1 Rubia Galega x Nelore (NRG), suplementados com cromo picolinato (CrP). Sessenta garrotes (30 NEL e $30 \mathrm{NRG}$ ) com peso corporal de $232,40 \mathrm{~kg}$ e idade média de 210 dias, foram distribuídos em delineamento inteiramente casualizado em esquema fatorial $2 \times 2$ (grupos genéticos $\mathrm{x}$ suplementações). O experimento foi de 335 dias, com 15 dias adaptação, dividido em 2 fases: fase recria (210 dias) e fase terminação (110 dias) e abatidos com 530 dias de idade. $\mathrm{Na}$ fase de recria os animais foram suplementados com $0,2 \%$ do peso corporal/dia (1,0mg CrP/kg suplemento), enquanto que na fase de terminação $0,5 \%$ do peso corporal/dia (0,5mg CrP/kg suplemento). Na fase de recria os animais NRG apresentaram ganho de peso médio diário (GMD) maior $(\mathrm{P}<0,001)$ que NEL $(0,65 \times 0,49 \mathrm{~kg} / \mathrm{dia})$, mas na fase de terminação o GMD foi semelhante $(\mathrm{P}=0,162)$ entre os grupos genéticos. A suplementação com $\mathrm{CrP}$ aumenta o ganho peso diário (ADWG) em $50 \mathrm{~g} /$ dia na fase de crescimento $(\mathrm{P}=0,021)$, porém ocorre perda na fase de acabamento de123 g/dia $(\mathrm{P}=0,005)$. O grupo genético e a dose de CrP não afetaram as características da carcaça ( $p>0,05)$.
\end{abstract}

Keywords: consumo; cromo; minerais; rendimento carcaça; ultrassom. 


\section{Introduction}

Brazil has the largest commercial herd in the world, with over 200 million heads. Eighty percent of the beef cattle in the country are Nellore or Nellore crossbred, amounting to 100 million heads (Ferraz and Felício, 2010).

One of the breeds with greatest muscularity is the Rubia Gallega. Recently introduced in Brazil and considered the most important breed in Spain, it is classified as high-meat-yielding, latematuring, with highly muscular carcasses and little fat cover (Albertí et al., 2005).

Given that the Brazilian beef cattle activity is based on a pasture regime and that cattle under such conditions are subject to possible deficiencies, one of which is mineral, supplementing these animals with minerals is a necessary practice (Moraes, 2001). One of the most important minerals is chromium, noteworthy for its action on the glucose and amino acid metabolisms (Sumner et al., 2007). Chromium is better absorbed in the form of organic complexes such as chromium picolinate $(\mathrm{CrP})$, the preferential compound in studies on cattle feeding (Lyons, 1997).

The use of chromium picolinate in the supplementation of cattle of different genetic groups may promote greater muscle development, improved carcass conformation, and better meat quality. The aim of this study was to evaluate the effect of supplementation with chromium picolinate on the production performance and carcass characteristics of Nellore and F1 Rubia Gallega $\times$ Nellore young bulls.

\section{Materials and methods}

\section{Experimental design and animal management}

The experiment was conducted in the north region of Mato Grosso State, Brazil (10 $50^{\circ} 15.65^{\prime \prime}$ S; 55'40'37.29” W). The study involved 60 young bulls (30 Nellore, NEL and 30 F1 Rubia Gallega $\times$ Nellore crossbred, RGN) at 210 days of age, with an initial body weight (IBW) of $232.40 \pm 3.57 \mathrm{~kg}$. All animals were kept on Brachiaria brizantha $\mathrm{cv}$. Marandu (24 ha) pastures, where they received mineral supplementation.

The experimental period was 335 days, including 15 days of adaptation to the supplementation, and divided into two stages: postweaning (210 days) and finishing stage (110 days). Supplements were provided at the rate of $0.2 \%$ of body weight per day in the post-weaning stage and $0.5 \%$ of body weight per day in the finishing stage (Table 1). The intake of the supplement in the treatments was $0.495 \mathrm{~kg}$ per day in post-weaning and $1.05 \mathrm{~kg}$ per day in the finishing.

\section{Evaluation of performance}

All animals were weighed every 14 days after being deprived of feed for $12 \mathrm{~h}$ to adjust their supplementation and determine the total body weight gain (TWG), average daily gain (ADG), percentage of weight gain (\%TWG), final body weight (FBW), slaughter weight (SW), final metabolic body weight $\left(\mathrm{FBW}_{\mathrm{m}}\right)$, metabolic body weight at slaughter $\left(\mathrm{SW}_{\mathrm{m}}\right)$, and average daily metabolic weight gain $\left(\mathrm{ADG}_{\mathrm{m}}\right)$.

\section{Tissue development}

For the evaluation of the muscle and adipose tissues, an ultrasound examination of the carcass $(n=60)$ was performed at the end of each stage (post-weaning and finishing) between the 12th and 13th ribs, transverse to the longissimus thoracis muscle, to evaluate the subcutaneous fat thickness (SFT) and the loin-eye area (LEA). The ratio between the $l$. thoracis height and width $(\mathrm{W} / \mathrm{H}$ ratio) was calculated. To evaluate bone tissue development, the shin circumference (SC) was measured at the medial portion of the left metatarsal bone using a 100-cm PVC tape measure.

\section{Carcass characteristics}

For the carcass characteristics, 26 animals (10 NEL and 16 RGN) with a minimum average body weight of $440 \mathrm{~kg}$ and 530 days of age were randomly selected. The animals were slaughtered in a local commercial packing plant, according to the regulations of the Brazilian Federal Inspection System (SIF). The carcasses were then chilled between -2 and $2^{\circ} \mathrm{C}$ for 24 hours.

To determine the hot carcass dressing percentage $(\mathrm{HCD}, \%)$, we divided the hot carcass weight $(\mathrm{HCW}, \mathrm{kg})$, obtained immediately before the carcass was sent to the cold storage room, by the fasted weight of cattle ( $\mathrm{SW}, \mathrm{kg}$ ) obtained one day before slaughter, as follows: $\mathrm{HCD}=\mathrm{HCW} / \mathrm{SW}$ $\times 100$.

The hot carcass was subjectively visually assessed at the end of the slaughter line, to determine conformation/muscularity (CONF) and the degree of fatness (DF) based on Felício (2003).

\section{Statistical analysis}

The study was developed as a completely randomized design in a $2 \times 2$ (two breed groups $\times$ 
two supplementations) factorial arrangement analyzed by the PROC MIXED procedure of the SAS software, with the animal as the random effect. For the production performance data, the
IBW of the sub-period (post-weaning and finishing) was adopted as a co-variable. In all analyses, 0.05 was defined as the maximum limit for type-I error.

Table 1. Levels of protein-energy supplement provided with $\mathrm{CrP}$ addition and in the growth and phinishing phases.

\begin{tabular}{lccl}
\hline \multicolumn{4}{c}{ Guaranteed levels (per kg) of supplement provided } \\
\hline Nutrients & Growth & Finishing & \\
\hline Protein & 20.00 & 16.00 & $\%$ \\
Ether Extract & $* *$ & 2.93 & $\%$ \\
Crude Fibre & $* *$ & 2.20 & $\%$ \\
Ash & $* *$ & 10.07 & $\%$ \\
Calcium & 2.60 & 2.95 & $\%$ \\
Phosphorus & 1.20 & 1.00 & $\%$ \\
Acid detergent fibre (ADF) & $* *$ & 4.05 & $\%$ \\
Total digestible nutrients (TDN) & 74.86 & 77.83 & $\%$ \\
Sodium & 3.70 & 1.12 & $\%$ \\
Magnesium & 0.26 & 0.30 & $\%$ \\
Sulfur & 0.36 & 0.28 & $\%$ \\
Copper & 164.31 & 87.49 & $\mathrm{mg} \mathrm{kg}^{-1}$ \\
Manganese & 72.37 & 48.10 & $\mathrm{mg} \mathrm{kg}^{-1}$ \\
Zinc & 510.18 & 262.24 & $\mathrm{mg} \mathrm{kg}^{-1}$ \\
Cobalt & 14.57 & 7.45 & $\mathrm{mg} \mathrm{kg}^{-1}$ \\
Iodine & 8.09 & 4.08 & $\mathrm{mg} \mathrm{kg}^{-1}$ \\
Selenium & 1.03 & 0.55 & $\mathrm{mg} \mathrm{kg}^{-1}$ \\
Fluorine & 106.49 & 80.81 & $\mathrm{mg} \mathrm{kg}^{-1}$ \\
Non-protein Nitrogen (NPN) & 2.18 & 0.80 & $\%$ \\
Equiv. NPN in Protein & 13.62 & 5.03 & $\%$ \\
Chromium Picolinate* & 1.00 & 0.50 & $\mathrm{mg} \mathrm{kg}^{-1}$ \\
\hline
\end{tabular}

\section{Results}

There was no interaction effect $(\mathrm{p}>0.05)$ between supplementation with $\mathrm{CrP}$ and genetic group for any of the production-performance or carcass-characteristics variables.

The use of $\mathrm{CrP}$ in supplementation promoted an increase in all production parameters $(\mathrm{p}<0.05)$, such as ADG, TWG, and FBW in the post-weaning stage (Table 2). Results revealed an effect of genetic group $(p<0.001)$ on the performance of RGN young bulls in relation to the NEL for all performance variables evaluated during the postweaning stage.

Table 2. Effects of supplementation with $\mathrm{CrP}$ and genetic group on the performance of Nellore and F1 Rubia Gallega $\times$ Nellore young bulls in the post-weaning stage.

\begin{tabular}{|c|c|c|c|c|c|c|c|}
\hline \multirow[b]{2}{*}{ Variable } & \multicolumn{2}{|c|}{ Supplementation } & \multicolumn{3}{|c|}{ Genetic group } & \multicolumn{2}{|c|}{$p$} \\
\hline & $\mathrm{CrP}$ & Control & NEL & RGN & CrP & GG & $\mathrm{CrP} \times \mathrm{GG}$ \\
\hline IBW (kg) & $232.40 \pm 3.57$ & $232.40 \pm 3.57$ & $232.40 \pm 3.57$ & $232.40 \pm 3.57$ & - & - & - \\
\hline ADG (kg) & $0.598 \pm 0.015$ & $0.548 \pm 0.015$ & $0.496 \pm 0.016$ & $0.650 \pm 0.016$ & 0.025 & $<0.001$ & 0.986 \\
\hline $\mathrm{ADG}_{\mathrm{m}}(\mathrm{kg})$ & $0.108 \pm 0.003$ & $0.099 \pm 0.003$ & $0.090 \pm 0.003$ & $0.117 \pm 0.003$ & 0.026 & $<0.001$ & 0.950 \\
\hline TWG (kg) & $125.57 \pm 3.15$ & $115.00 \pm 3.15$ & $104.11 \pm 3.48$ & $136.46 \pm 3.48$ & 0.025 & $<0.001$ & 0.982 \\
\hline$\% \mathrm{TWG}$ & $54.04 \pm 1.38$ & $49.62 \pm 1.38$ & $44.87 \pm 1.52$ & $58.79 \pm 1.52$ & 0.031 & $<0.001$ & 0.863 \\
\hline FBW (kg) & $357.97 \pm 3.15$ & $347.40 \pm 3.15$ & $336.51 \pm 3.48$ & $368.86 \pm 3.48$ & 0.025 & $<0.001$ & 0.982 \\
\hline $\mathrm{FBW}_{\mathrm{m}}(\mathrm{kg})$ & $82.21 \pm 0.55$ & $80.37 \pm 0.55$ & $78.48 \pm 0.61$ & $84.10 \pm 0.61$ & 0.026 & $<0.001$ & 0.930 \\
\hline
\end{tabular}

NEL: Nellore; RGN: F1 Rubia Gallega $\times$ Nellore; CrP: chromium picolinate supplementation; GG: genetic group; PW: postweaning; $\mathrm{CrP} \times \mathrm{GG}$ : supplementation vs. genetic group interaction.

IBW: initial body weight; ADG: average daily weight gain; $\mathrm{ADG}_{\mathrm{m}}$ : average daily metabolic weight gain; TWG: total body weight gain; \%TBW: percentage of total body weight gain; FBW: final body weight; $\mathrm{FBW}_{\mathrm{m}}$ : final metabolic body weight. $\mathrm{p}<0.05$. 
Performance data obtained during the finishing stage is described in Table 3. No difference was found $(\mathrm{p}>0.05)$ between the genetic groups $(\mathrm{NEL} \times \mathrm{NGR})$, although the use of $\mathrm{CrP}$ in supplementation significantly changed $(\mathrm{p}<0.05)$ the performance. Bulls that were not supplemented with $\mathrm{CrP}$ had an improvement in their production rates during this stage. In the finishing stage (Table 3), there were differences for $\mathrm{ADG}$ and $\mathrm{ADG}_{\mathrm{m}}$ ( $\mathrm{p}=0.005$ and $\mathrm{p}=0.004$, respectively); TWG and $\%$ TWG ( $\mathrm{p}=0.005)$; or $\mathrm{SW}$ and $\mathrm{SW}_{\mathrm{m}}(\mathrm{p}=0.005$ and $\mathrm{p}=0.004$, respectively) between the treatments with and without $\mathrm{CrP}$ supplementation.

Table 3. Effects of supplementation with $\mathrm{CrP}$ and genetic group on the performance of Nellore and F1 Rubia Gallega $\times$ Nellore young bulls in the finishing stage.

\begin{tabular}{|c|c|c|c|c|c|c|c|}
\hline \multirow[b]{2}{*}{ Variable } & \multicolumn{2}{|c|}{ Supplementation } & \multicolumn{2}{|c|}{ Genetic group } & \multicolumn{3}{|c|}{$p$} \\
\hline & CrP & Control & NEL & RGN & $\mathrm{CrP}$ & GG & $\mathrm{Cr} \times \mathrm{GG}$ \\
\hline IBW (kg) & $352.68 \pm 4.69$ & $352.68 \pm 4.69$ & $352.68 \pm 4.69$ & $352.68 \pm 4.69$ & - & - & - \\
\hline ADG (kg) & $0.735 \pm 0.028$ & $0.858 \pm 0.028$ & $0.813 \pm 0.035$ & $0.780 \pm 0.035$ & 0.005 & 0.575 & 0.531 \\
\hline $\mathrm{ADG}_{\mathrm{m}}(\mathrm{kg})$ & $0.124 \pm 0.005$ & $0.144 \pm 0.005$ & $0.137 \pm 0.006$ & $0.131 \pm 0.006$ & 0.004 & 0.591 & 0.573 \\
\hline TWG (kg) & $83.07 \pm 3.16$ & $96.93 \pm 3.16$ & $91.90 \pm 4.01$ & $88.10 \pm 4.01$ & 0.005 & 0.574 & 0.531 \\
\hline$\%$ TWG & $23.91 \pm 0.95$ & $28.02 \pm 0.95$ & $26.29 \pm 1.21$ & $25.64 \pm 1.21$ & 0.005 & 0.752 & 0.834 \\
\hline SW (kg) & $435.76 \pm 3.15$ & $449.61 \pm 3.16$ & $444.58 \pm 4.01$ & $440.78 \pm 4.01$ & 0.005 & 0.574 & 0.531 \\
\hline $\mathrm{SW}_{\mathrm{m}}(\mathrm{kg})$ & $95.30 \pm 0.51$ & $97.57 \pm 0.51$ & $96.74 \pm 0.65$ & $96.13 \pm 0.65$ & 0.004 & 0.582 & 0.522 \\
\hline
\end{tabular}

NEL: Nellore; RGN: F1 Rubia Gallega $\times$ Nellore; CrP: chromium picolinate supplementation; GG: genetic group; PW: postweaning; $\mathrm{CrP} \times \mathrm{GG}$ : supplementation vs. genetic group interaction.

IBW: initial body weight; ADG: average daily weight gain; ADGm: average daily metabolic weight gain; TWG: total body weight gain; \%TWG: percentage of total body weight gain; SW: slaughter weight; SWm: metabolic slaughter weight. $\mathrm{p}<0.05$.

None of the carcass traits was influenced by the use of $\mathrm{CrP}$ in the animal supplementation (Table 4). The RGN bulls had a higher $(\mathrm{p}=0.049)$ hot carcass weight $(\mathrm{HCW})$ than NEL, but the hot carcass dressing percentage (HCD) was similar $(\mathrm{p}=0.288)$ between the groups, averaging $55.8 \%$, which is higher than mean values reported in other studies.

Table 4. Effects of supplementation with $\mathrm{CrP}$ and genetic group on carcass characteristics of Nellore and $\mathrm{F} 1 \mathrm{Rubia}$ Gallega $\times$ Nellore young bulls.

\begin{tabular}{lccccccc}
\hline \multirow{2}{*}{ Variable } & \multicolumn{2}{c}{ Supplementation } & \multicolumn{2}{c}{ Genetic group } & \multicolumn{2}{c}{$\boldsymbol{p}$} \\
\cline { 2 - 8 } & CrP & Control & NEL & RGN & CrP & GG & GG $\times$ CrP \\
\hline SW (kg) & $454.8 \pm 12.0$ & $457.8 \pm 11.9$ & $445.8 \pm 13.7$ & $466.8 \pm 10.2$ & 0.098 & 0.807 & 0.938 \\
HCW (kg) & $254.9 \pm 7.2$ & $254.8 \pm 7.2$ & $247.6 \pm 8.2$ & $262.1 \pm 6.2$ & 0.049 & 0.980 & 0.865 \\
HCD (\%) & $56.1 \pm 0.5$ & $55.6 \pm 0.5$ & $55.5 \pm 0.5$ & $56.2 \pm 0.4$ & 0.288 & 0.478 & 0.517 \\
CONF (1-5) & $3.6 \pm 0.15$ & $4.1 \pm 0.14$ & $3.9 \pm 0.17$ & $3.7 \pm 0.12$ & 0.057 & 0.149 & 0.447 \\
DF (1-5) & $2.2 \pm 0.18$ & $2.3 \pm 0.18$ & $2.2 \pm 0.21$ & $2.3 \pm 0.16$ & 0.626 & 0.797 & 0.078 \\
\hline
\end{tabular}

NEL: Nellore; RGN: F1 Rubia Gallega $\times$ Nellore; CrP: chromium picolinate supplementation; GG: genetic group; PW: postweaning; $\mathrm{CrP} \times \mathrm{GG}$ : supplementation vs. genetic group interaction.

SW: slaughter weight; HCW: hot carcass weight; HCD: hot carcass dressing percentage; CONF: conformation - muscularity index; DF: degree of fatness of the carcass. $\mathrm{p}<0.05$.

Tissue (muscle, fat, and bone) development data during the post-weaning and finishing stages are described in Table 5. The use of CrP did not influence $(p>0.05)$ the muscularity or fatness variables. RGN young bulls were superior $(\mathrm{p}<0.05)$ for loin-eye area in comparison with the NEL during the entire experimental period. This superiority was present both at the end of the postweaning stage and in the finishing period ( $<<0.001$ ), demonstrating that animals with Rubia Gallega genetics have greater muscle development until slaughter.

\section{Discussion}

Supplementation with $\mathrm{CrP}$ during the postweaning stage increased $(p=0.025)$ the final body weight (FBW) in relation to control animals, with a difference in total weight gain (TWG) of 10.57 $\mathrm{kg}(\mathrm{p}=0.025)$. For the percentage of total body weight gain (\% TBW), the animals consuming $\mathrm{CrP}$ were more efficient by 4.42 points $(p=0.031)$ in relation to those without $\mathrm{CrP}$, and the average daily gain (ADG) was higher by $50 \mathrm{~g}$, also influencing the average daily metabolic gain $\left(\mathrm{ADG}_{\mathrm{m}}\right)$ of the animals supplemented with $\mathrm{CrP}(\mathrm{p}=0.026)$. A com- 
parison of final metabolic body weight $\left(\mathrm{FBW}_{\mathrm{m}}\right)$ data in the post-weaning period showed that this difference remained $(\mathrm{p}=0.026)$. The animals consuming $\mathrm{CrP}$ were higher by $1.84 \mathrm{~kg}$ as compared with those without $\operatorname{CrP}(82,21 \times 80,37)$, demonstrating that supplementation with $\mathrm{CrP}$ is efficient in increasing body weight during this stage.

Table 5. Effects of supplementation with $\mathrm{CrP}$ on tissue development of Nellore and F1 Rubia Gallega $\times$ Nellore young bulls.

\begin{tabular}{|c|c|c|c|c|c|c|c|}
\hline \multirow{2}{*}{ Variable } & \multicolumn{2}{|c|}{ Supplementation } & \multicolumn{2}{|c|}{ Genetic group } & \multicolumn{3}{|c|}{$p$} \\
\hline & $\mathrm{CrP}$ & Control & NEL & RGN & $\mathrm{CrP}$ & GG & Cr $\times$ GG \\
\hline \multicolumn{8}{|l|}{ LEA (cm) } \\
\hline PW & $43.4 \pm 3.1$ & $45.3 \pm 3.1$ & $36.1 \pm 3.1$ & $52.6 \pm 3.1$ & 0.537 & $<0.001$ & 0.140 \\
\hline Finishing & $59.8 \pm 1.7$ & $57.0 \pm 1.7$ & $53.4 \pm 1.7$ & $63.4 \pm 1.70$ & 0.110 & $<0.001$ & 0.450 \\
\hline \multicolumn{8}{|l|}{ LEA/100 kg } \\
\hline PW & $12.1 \pm 0.9$ & $12.9 \pm 0.9$ & $11.2 \pm 0.9$ & $13.8 \pm 0.9$ & 0.387 & $<0.001$ & 0.159 \\
\hline Finishing & $13.7 \pm 0.4$ & $12.8 \pm 0.4$ & $12.9 \pm 0.40$ & $13.6 \pm 0.4$ & 0.064 & 0.133 & 0.516 \\
\hline \multicolumn{8}{|l|}{ SFT (mm) } \\
\hline PW & $2.2 \pm 0.2$ & $2.2 \pm 0.2$ & $2.0 \pm 0.2$ & $2.4 \pm 0.2$ & 0.779 & 0.122 & 0.985 \\
\hline Finishing & $3.4 \pm 0.2$ & $3.7 \pm 0.2$ & $3.5 \pm 0.2$ & $3.6 \pm 0.2$ & 0.088 & 0.930 & 0.199 \\
\hline \multicolumn{8}{|l|}{$\mathrm{W} / \mathrm{H}$ ratio } \\
\hline PW & $0.48 \pm 0.02$ & $0.39 \pm 0.02$ & $0.41 \pm 0.02$ & $0.46 \pm 0.02$ & 0.002 & 0.040 & 0.116 \\
\hline Finishing & $0.44 \pm 0.01$ & $0.42 \pm 0.01$ & $0.42 \pm 0.01$ & $0.44 \pm 0.01$ & 0.216 & 0.171 & 0.757 \\
\hline \multicolumn{8}{|l|}{$\mathrm{SC}(\mathrm{cm})$} \\
\hline PW & $19.0 \pm 0.6$ & $18.3 \pm 0.6$ & $17.9 \pm 0.6$ & $19.4 \pm 0.6$ & 0.332 & 0.020 & 0.293 \\
\hline Finishing & $21.5 \pm 0.2$ & $21.6 \pm 0.2$ & $21.1 \pm 0.2$ & $22.0 \pm 0.2$ & 0.823 & $<0.001$ & 0.922 \\
\hline
\end{tabular}

The present results corroborate those by Polizel Neto et al. (2009), who found similar gains in Nellore and F1 Brangus $\times$ Nellore young bulls supplemented with $\mathrm{Cr}$ complexed with the organic matter. These animals obtained a daily gain of $74 \mathrm{~g}$ per animal when compared with those supplemented without $\mathrm{Cr}$. Chang and Mowat (1992) evaluated the effect of $\mathrm{Cr}$ on the performance of young male cattle and obtained gains higher than those reported here, with $\mathrm{Cr}$ supplementation increasing their gain by 150 g/animal/day. However, this weight gain occurred during the first weeks after situations of intense stress caused by transportation and auctions. Kegley et al. (1997) also obtained a higher weight gain with $\mathrm{Cr}$ supplementation in animals subjected to situations of stress, similarly to our findings, since the experimental period began soon after the animals were weaned.

Significant effects of $\mathrm{Cr}$ supplementation are related to occurrences of stressful periods during the experiments, because, during stress, the glucose metabolism reduces simultaneously to an increase in secretion of the cortisol hormone in the blood (Oliveira and Soares Filho, 2005).
As shown in Table 2, the RGN animals in the post-weaning stage had a higher $\mathrm{FBW}$ and $\mathrm{FBW}_{\mathrm{m}}$ $(\mathrm{p}<0.001)$ by $32.35 \mathrm{~kg}$ and $5.62 \mathrm{~kg}$, respectively. Average daily gain was higher for the RGN by 160 $\mathrm{g} /$ day on average $(\mathrm{p}<0.001)$, and TWG was also higher, resulting in a difference of $32.35 \mathrm{~kg}$. This fact corroborates the findings of other researchers, considering taurine animals have greater musclegrowth ability as compared with zebu cattle (Morales et al., 2002).

The present results also support Galvão et al. (1991), who found Nellore animals to have a lower ADG than crossbred cattle. Bonilha (2007) observed differences in the performance of crossbred animals as well in relation to pure Nellore for the weights of entry and exit from the feedlot, with higher results found for the crossbred.

In the post-weaning stage, the RGN bulls were more efficient than the NEL in \%TWG by 13.92 percentage points, which was a significant difference. For $\mathrm{ADG}_{\mathrm{m}}$, the $\mathrm{RGN}$ animals were superior by $27 \mathrm{~g} /$ day, characterizing their better performance $(p<0.001)$ during this period.

According to Table 3, the production performance of the animals during the finishing sta- 
ge was not influenced by the genetic group. There was no difference ( $p>0.05)$ in ADG, TWG, and SW expressed in percentage terms or in metabolic weight between the NEL and RGN groups. These findings contrast with results published by Jorge et al. (1999), who reported that Nellore cattle usually have lower weight gains compared with beef-origin European-Zebu crossbred. Galvão et al. (1991) and Estrada (1997), also reported lower weight gains in Nellore animals as compared with taurine crossbred.

Albertí et al. (2005) analyzed seven Spanish beef breeds for carcass characteristics and reported that the Rubia Gallega breed had larger carcasses, with higher slaughter weights than the others. The RGN genetic group did not maintain the production superiority shown in the post-weaning stage during the finishing period, suggesting that the animals of that genetic group had their growth rate declined during the finishing stage, which marks the end of the period of intense muscle growth that occurs until puberty.

Bianchini et al. (2008), studied the growth and carcass features of Nellore, Simmental, and crossbred cattle and concluded that as the Nellore genetic was introduced, the time in the feedlot required to obtain the target weight and degree of fatness was increased. This is explained by the difference in earliness for muscle tissue growth between the genetic groups, which is lower in the zebu.

According to Owens (1993), the postweaning stage is characterized by an accelerated increase in the growth curve resulting from the development of the bone and muscle tissues, activated by the release of growth hormones; in this situation, the muscle tissue synthesis is higher than that of adipose tissue. During the post-natal growth period of the animal, muscle growth occurs only by hypertrophy (increased cell diameter), mainly by a protein accretion (Buttery, 1981) that is potentiated by $\mathrm{Cr}$, because the latter, in addition to its main action on the metabolism of carbohydrates, also participates in the protein metabolism. In this way, it stimulates the capture of amino acid by cells, as it is directly linked to the insulin activity (Ewelina, 2010).

Because most mammals have between 40 and $50 \%$ of their body weight composed of muscles, regardless of species or sex (Buttery, 1981), this muscle growth has a strong influence on body weight gain.
Thus, the animals supplemented with $\mathrm{CrP}$ had an accelerated muscle development during the post-weaning stage, reaching an elevated level of muscle-cell filling earlier; this development declined during the finishing stage, when the animals supplemented without $\mathrm{CrP}$ were still under muscle development and thus in a faster growth than those receiving $\mathrm{CrP}$.

As the animal reaches its adult weight (maturity weight), there is a decline in protein deposition rate and an increase in the development of adipose tissue that result in increases in the energy requirements for body weight gain.

Likewise, other authors did not observe an effect of chromium supplementation on the performance of finishing cattle (Danielsson and Pehrson, 1998; Depew et al. 1998), demonstrating that the action of $\mathrm{CrP}$ is not very efficient in the finishing stage.

Under normal conditions, it appears that the chromium levels present in finishing diets are sufficient for the adequate development of animals. In special conditions, like in stressful situations, many studies have shown a positive effect of supplementation with organic chromium (Zanetti et al., 2003).

In terms of carcass dressing percentage, Santos et al. (2002) evaluated supplementation and carcass characteristics of Nellore $\times$ Limousin crossbreed cattle under similar pasture conditions, with various supplementation levels, and obtained $246.3 \mathrm{~kg} \mathrm{HCW}$ and $53.6 \% \mathrm{HCD}$.

Muscularity characteristics (CONF) and carcass fatness (FD) were not influenced by $\mathrm{CrP}$ or genetic group ( $>00.05)$. Vaz and Restle (2001) studied the effect of breed and heterosis on the carcass characteristics of young male cattle and found a higher growth rate in Charolais cattle in relation to the Nellore, although the latter had higher HCD and DF, unlike the observations of the present study, in which no significant differences occurred. Galvão (1991), on the other hand investigated the weight gain, feed intake and feed conversion of uncastrated cattle of three breed groups slaughtered at different maturity stages and defined better carcass dressing percentage as being a characteristic of zebu breeds.

As Nellore animals have a smaller frame size in comparison with the Rubia Gallega, they would require more days along finishing period to reach similar weight and LEA to that of the RGN group. This is explained by the fact that the NEL have slower muscle development. 
Because the LEA measured by the ultrasound is positively correlated with live weight (Suguisawa, 2002), we can infer that the higher LEA values shown in Table 5 for the RGN genetic group agreed with the higher weights for this group in the post-weaning stage. In this way, comparing LEA and its ratio with $100 \mathrm{~kg}$ live weight, a significant difference $(\mathrm{p}<0.001)$ is only observed for the end of the finishing period. In this regard, the evaluation of LEA width/height ratio (W/H ratio) confirm the data obtained for LEA relative to live weight, where the RGN animals were superior to the NEL at the end of the post-weaning stage $(\mathrm{p}=0.04)$.

The effect of supplementation with $\mathrm{CrP}$ on tissue development was similar in both the postweaning and finishing stages. However, the $\mathrm{W} / \mathrm{H}$ ratio was higher with the addition of $\mathrm{CrP}(0.48$ for $\mathrm{CrP}$; 0.39 for control) in the early post-weaning period $(\mathrm{p}=0.002)$, unlike LEA $/ 100 \mathrm{~kg}$ in the same period $(\mathrm{p}=0.387)$.

Subcutaneous fat thickness (SFT) was not influenced by the genetic groups ( $\mathrm{p}=0.122$ postweaning; $p=0.930$ finishing) or by supplementation with $\mathrm{CrP} \quad(\mathrm{p}=0.779$ post-weaning; $\mathrm{p}=0.088$ finishing). This contrasts with the findings described by Mooney and Cromwell (1997), who observed a reduction in fat deposition with $\mathrm{Cr}$ supplementation, and also Prado et al. (2004), who studied different methods for the evaluation of loin-eye area and fat cover in beef cattle and observed a significant difference for SFT comparing Nellore and Brangus animals. Agreeing with these results, Rotta et al. (2009), stated that the fat thickness is one of the main parameters affected by sex, with heifers $(4.00 \mathrm{~mm})$ showing higher values than bulls $(1.75 \mathrm{~mm})$ and oxen $(2.81 \mathrm{~mm})$.

Dal Farra (2002) studied nutrition and management techniques and Arrigoni (2003) studied the production efficiency of beef cattle in steers subjected to the super-early biological method and both concluded that animals larger at maturity, such as the Rubia Gallega, have a more accelerated growth and higher muscle development. By contrast, Nellore animals are earlier in adipose tissue deposition (Brondani et al., 2006).

For shin circumference (SC), there was a significant difference $(\mathrm{p}=0.020$ post-weaning; $\mathrm{p}<0.001$ finishing) between breed groups, with RGN animals having higher values than the NEL, demonstrating a larger bone structure of the former. According to Owens et al. (1993), this related to the growth rate and consequently to the differentiated metabolism between the breeds. However, the use of $\mathrm{CrP}$ did not promote differences $(\mathrm{p}>0.05)$ between treated groups.

\section{Conclusion}

Supplementation with chromium picolinate improves the muscle growth of uncastrated young bulls during the post-weaning stage. The F1 Rubia Gallega $\times$ Nellore young bulls showed better muscle and bone tissue development than the Nellore animals, suggesting that the Rubia Gallega genetics is an alternative for an early slaughter of uncastrated young bulls with shorter production cycles.

\section{Conflict of interest}

The authors declare that there is no conflict of interest.

\section{Ethics Committee}

All procedures in this trial were approved by the ethics committee for animal research (CEPA) of Universidade Federal de Mato Grosso, Brazil (code number 410/2014).

\section{References}

Alberti, P.; Ripoll, G.; Goyache, F.; Lahoz, F.; Olleta, J.L.; Panea, B.; Sanudo, C. Carcass characterization of seven Spanish beef breeds slaughtered at two commercial weights. Meat Science, 71 :514-521, 2005.

Arrigoni, M.B. Eficiência produtiva de bovinos de corte: modelo biológico superprecoce. Botucatu: FMVZ/UNESP. 428p. 2003.

Bianchini, W.; Silveira, A.C.; Arrigoni, M.B.; Jorge, A.M.; Martins, C.L.; Rodrigues, E. Crescimentos e características de carcaça de bovinos superprecoces Nelore, Simental e mestiços. Revista Brasileira Saúde Produção Animal [online], 9(3):554-564, 2008.

Brondani, I.L.; Sampaio, A.A.M.; Restle, J.; Alves Filho, D.C.; Freitas, L.S.; Amaral, G. A.; Silveira, M.F.; Cezimbra, I.M. Composição física da carcaça e aspectos qualitativos da carne de bovinos de diferentes raças alimentados com diferentes níveis de energia. Revista Brasileira Zootecnia, 35(5): 20342042, 2006.

Bonilha, S.F.M; Packer, L.A; Figueiredo, G.F; Alleoni, F.D; Resende, A.G. Efeitos da seleção para peso pós-desmame sobre características de carcaça e rendimento de cortes cárneos 
comerciais de bovinos. Revista Brasileira de Zootecnia, 36(5): 1275-1281, 2007

Chang, X.; Mowat, D.N. Supplement Chromium for stress and growing feeder calves. Journal Animal Science, 70:559-565, 1992.

Dal-Farra, R. A.; Roso, V. M.; Schenkel, F. S. Efeitos de ambiente e de heterose sobre o ganho de peso do nascimento ao desmame e sobre os escores visuais ao desmame de bovinos de corte. Revista Brasileira de Zootecnia, 31(3): 1350-1361, 2002.

Danielson, D.A.; and Pehrson, B. Effects of chromium supplementation on the growth and carcass quality of bull fed a grain-based diet during the finishing period. Journal Veterinary Medicine, Series A-Pathology and Clinical Medicine, 45(4):219-224, 1998.

Depew, C.L; Bunting, L.D.; Fernadez, J.M. Performance and metabolic responses of young dairy calves fed diets supplemented with chromium tripicolinate. Journal Dairy Science, 81(11): 2916-2923, 1998.

Estrada, L.H.C.; Fontes, C.A.A.; Jorge, A.M.; Martins, M.; Freitas, J.A.; Queiroz, A.C. Exigências Nutricionais de bovinos não castrados em confinamento. 1. Conteúdo corporal e exigências líquidas de proteína e energia para ganho de peso. Revista Brasileira de Zootecnia, 26(3):575-583, 1997.

Ewelina, K; Krejpcio, Z. Chromium(III) propionate complex supplementation improves carbohydrate metabolism in insulin-resistance rat model. Food and Chemical Toxicology. 8: 2791-2796, 2010.

Felício, P.E. Classificação de carcaça bovina. Parte I. Critérios terão que facilitar o comércio por meios eletrônicos. Revista ABCZ, 3(14): 164, 2003.

Ferraz, J.B.S.; Felício, P.E. Production systems An example from Brazil. Meat Science. 4:238243, 2010.

Ferrell, C.L. and Jenkins, T.G. Cow type and the nutritional environment: Nutritional aspects. Journal of Animal Science, 61(3):725-741, 1985.

Galvão, J.G.; Fontes, C.C.A.; Pires, C.C.; Queiroz, A.C. Ganho de peso, consumo e conversão alimentar em bovinos não castrados, de três grupos raciais, abatidos em diferentes estágios de maturidade. Revista Sociedade Brasileira de Zootecnia, 20:494-501, 1991.

Jorge, A.M.; Fontes, C.A.A.; Paulino, M.F.; Gomes Júnior, P.; Ferreira, J.N. Desempenho produtivo de animais de quatro raças zebuínas, abatidos em três estádios de maturidade 2 . Características da carcaça. Revista Brasileira de Zootecnia, 28: 381-387, 1999.

Kegley, E.B.; Spears, J.W.; Brown, T. Effects of shipping and chromium supplementation on performance, immune response, and disease resistance of steers. Journal of Animal Science, 75:1956-1962, 1997.

Lyons, P. A new era in animal production: the arrival of the scientifically proven natural alternatives. In: Symposium Biotechnology in the feed industry, 13, 1997. Proceedings of Alltech... Nottinghan: Univ. Press, p. 241-250, 1997.

Mooney, K.W.; Cromwell, G.L. Efficacy of chromium picolinate and chromium chloride as potential modifiers in swine. Journal of Animal Science, 75:2661-2671, 1997.

Moraes, S.S. Novos microelementos minerais e minerais quelatados na nutrição de bovinos. Documentos 119. Embrapa. Campo Grande MT. p. 11. 2001

Morales, D.C.; Chardulo, L.A.L.; Silveira, A.C.; Oliveira, L.H.; Arrigoni, M.B.; Martins, C.L.; Cervieri, R.C. Características de qualidade de carne de bovinos de cortes de diferentes tamanhos à maturidade submetidos ao sistema superprecoce. Acta Scientiarum, 24(4):1-2, 2002.

Oliveira, D.J.C.; Soares Filho, C.V. Suplementação com cromo para ruminantes. Arquivos de Ciências Veterinárias e Zoologias da UNIPAR, 8(1): 71-77, 2005.

Owens, F.N.; Dubeski, P.; Hanson, C.F. Factors that alter the growth and development of ruminants. Journal of Animal Science, 71:3138-3150, 1993.

Polizel Neto, A.; Jorge, A.M.; Moreira, P.S.A; Gomes, H.B.; Pinheiro, R.S.B. Desempenho e qualidade da carne de bovinos Nelore e F1 Brangus $\times$ Nelore recebendo suplemento com cromo complexado à molécula orgânica na terminação a pasto. Revista Brasileira de Zootecnia, 38(14):737-745,2009.

Prado, C. S.; Pádua, J.T.; Correa, M.P.C. Comparação de diferentes métodos de avaliação da área de olho de lombo e cobertura de gordura em bovinos de corte. Ciência Animal Brasileira, 5(3):141-149, 2004.

Rotta, P.P.; Prado, R.M.; Prado, I.N.; Valero, M.V.; Visentaine, J.V.; Silva, R.R.. The Effects of Genetic Groups, Nutrition, Finishing 
Systems and Gender of Brazilian Cattle on Carcass Characteristics and Beef Composition and Appearance: A Review. AsianAustralasian Journal of Animal Science, 22(12): 1718-1734, 2009.

Santos E.D.G., Paulino M.F., Lana R.P. 2002. Influência da suplementação com concentrado nas características de carcaça de bovinos F1 Limousin Nelore, não castrados, durante a seca, em pastagens. Revista Brasileira de Zootecnia, 31(4):1823-1832, 2002.

Statistical Analysis System. The SAS system for Windows release 9.0. 2002. Cary, NC: SAS Institute. 1 CD-ROM

Suguisawa, L.; Mattos, W.R.S.; Souza, A.A.; Silveira, A.C.; Oliveira, H.N.; Arrigoni, M.B.; Burini, D.C.M. Ultra-sonografia para predição da composição da carcaça de bovinos jovens.
Revista Brasileira de Zootecnia, 35(1): 177185, 2006.

Sumner, J.M.; Valdez, F.; Mcnamara, J.P. Effects of chromium propionate on response to an intravenous glucose tolerance test in growing Holstein heifers. Journal of Dairy Science, 90:3467-3474, 2007.

Vaz, F.N.; Restle, J. Efeito de raça e heterose para características de carcaça de novilhos da primeira geração de cruzamento entre Charolês e Nelore. Revista Brasileira de Zootecnia, 30(2):409-416, 2001.

Zanetti, M.A.; Salles, M.S.V.; Brisola, M.L.; Cesar, M.C. Desempenho e resposta metabólica de bezerros recebendo dietas suplementadas com cromo. Revista Brasileira de Zootecnia, 32(6):1532-1535, 2003. 